\title{
Leadership succession patterns in the apostolic church as a template for critique of contemporary charismatic leadership succession patterns
}

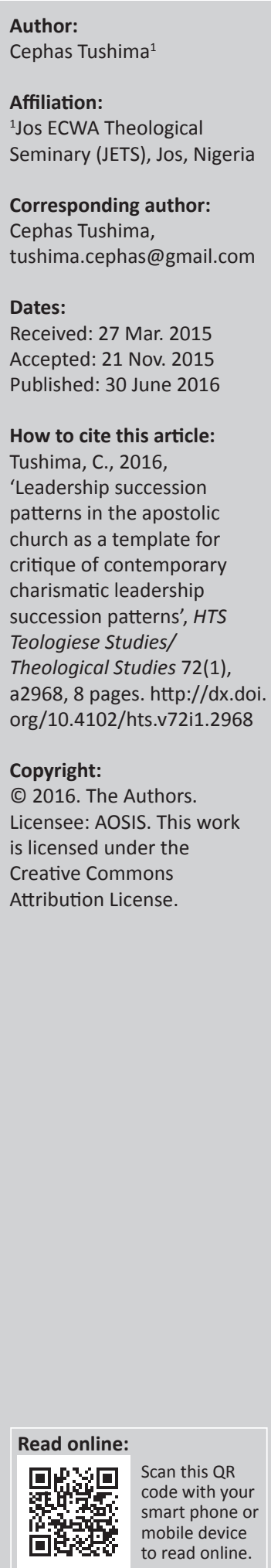

The pattern of leadership succession observed globally in most contemporary Pentecostal movements and churches can be characterised as dynastic succession. Yet historic modern Pentecostalism (in the Azusa tradition) prided itself on being biblical. This article explores the biblical sources, examining first the leadership structure and then the leadership succession patterns in the apostolic church as well as the extra-biblical sources of the apostolic patristic era. Our findings from this New Testament (and patristic sources) survey of leadership succession in the apostolic church and post-apostolic churches furnish a template for critical evaluation of the prevalent succession approaches of contemporary Pentecostal groups. Critical elements of apostolic and leadership structure and succession patterns are highlighted, and needed inferences are drawn for the re-shaping of leadership and its succession in contemporary Christian ministries and churches.

\section{Introduction}

Leadership succession has been of interest to humanity from time immemorial. In the Scripture, succession concerns are evident early in the Genesis account of human origins. These concerns become heightened in the narratives of the patriarchs, as in Abraham's lament about not having an heir (Gn. 15:3). Subsequently, owing to the fulfilment of the divine promise of progeny, we see the succession of one patriarch after another till the birth of the nation in the 12 tribes of Israel. Similarly, the same concerns surfaced early in the life of Israel during the wilderness wandering period, when Moses, their leader, in view of his approaching death, became concerned that at his demise, Israel would not be as sheep without a shepherd, and in response to that concern, Yahweh elected Joshua as Moses' successor (Nm. 27:12-23). The death of Joshua created a leadership vacuum that was the bane of Israel throughout the period of the judges until the rise of the monarchy. Even during the monarchy, leadership was never without challenges. The dynastic struggle between the house of Saul and the house of David as well as the internecine feuds within the house of David were aspects of the challenges and problems of leadership succession.

The New Testament is not without its own challenges and options for leadership succession. While the gospels do not directly address matters of succession, they do not neglect them. The contest between the twelve apostles for supremacy, as Jesus began to talk about his departure from the earth, is telling. As MacDonald (1981) observes:

One of the most perplexing concepts for Jesus' disciples to grasp was that of the nature of this unique kingdom whose source, means and end was God. Yet the great truths about God's reign had been presented to them early and repeatedly in their adventure with Jesus. (p. 27)

Yet right up close to his passion, the sons of Zebedee in concert with their mother (an aunt of Jesus), for instance, were jostling for the place of rank (successors-in-waiting, so to say), as the Master's closest relatives (first cousins) among his band of disciples (Morris 1982:1107).

Even after the resurrection, the thinking of the apostles was still warped and wrapped up in thisworldly kingdom concepts. MacDonald (1981) notes:

What does impress us here, however, about the apostles' slow comprehension of the character of the kingdom over which God would rule was this: After three years of observing close up Jesus' message and methods, they were still, contrary to what they had seen and heard, hoping for a 'regular' kingdom. (p. 27)

It is not surprising that two millennia after Pentecost, that some people are still building personal kingdoms instead of the kingdom of God. The thesis of this article is that ministers of the gospel who are focused on honouring God and labouring to advance his kingdom, upon their departure 
from the earth, naturally bequeath any structures arising from their efforts to those who share a common vision with them. Conversely, those fixated on building personal kingdoms seek, by any means, to ensure that their family members 'receive' the call to the ministry and take over the empires they have built over the years, instead of allowing for a natural succession from within the ranks of those of have ministered alongside the founding leaders.

The pattern of leadership succession observed in contemporary Pentecostal and charismatic movements and churches often is characterised by dynastic succession of the kind more often found in personal kingdoms than in the kingdom of God. Personal kingdoms is used here in reference to the situation where the president and founder of a Christian ministry exercises absolute sole proprietary right and control over its operations and (especially) finances. It is used in a similar way to Ngomane's term family empires (2013:50). Key appointments and positions of influence (and especially those that have anything to with ministry funds) are given to trusted family members. Funds raised from the ministry are used to advance the economic fortunes and social status of the family in society. To keep the wealth that accrues from this ministry endeavour within the family, therefore, all efforts are made to ensure that successors to the president-founder are family members, hence, the idea of dynastic succession. Yet historic modern Pentecostalism (in the Azusa tradition) prided itself on being biblical. I intend to return to the biblical and early Christians sources (following the Renaissance clarion call of recursus ad fontes) to examine the pattern of leadership succession in the apostolic and the post-apostolic church. The findings from the New Testament survey of leadership succession in the apostolic church will form the template for a critical evaluation of the prevalent approaches to succession of contemporary charismatic and Pentecostal groups. Ultimately, I shall suggest a way forward in leadership succession to the Pentecostal church of the twenty first century.

\section{Conceptual framework: features of classical Pentecostalism}

The origins of the modern Pentecostal movement are well rehearsed and I will forebear repeating the details here (Burkett \& Newman 1978:213-225; Tinney 1976:34-44; Turner 2007:32-45). Suffice it to mention that nascent manifestations of this emergent movement that will attain global proportions began to be felt in the holiness movement in the late 1800s. Charles F. Parham was one of the earliest promoters of the Pentecostal ministry in the early 1900s in the Houston, Texas area. However, the lot fell to the one-eyed, black church elder William J. Seymour to be the one to open the gates to the great torrent of the global Pentecostal movement through the Azusa Street Mission revivals that began on 9 April 1906 (Cauchi 2004).

Classical Pentecostalism, in the Azusa Street order, consisted in believing in and living out the 'full gospel'. This implies having the salvation experience of personally accepting Jesus into one's life, sanctification by repentance from and renunciation of worldliness, rejection of rigid traditions and legalism of man-made religion, baptism in the Holy Spirit with the evidence of speaking in tongues, stress on the efficacy of fervent praying (often with fasting), the experience of bodily divine (miraculous) healings and the eschatological expectation of the soon (pre-millennial) return of Christ (Macchia 1996:33). In such a context, succession tended to be bestowed on those who most imbibed the ethos of the movement as was seen in many of the early Pentecostal Assemblies, Full Gospel Assemblies, Apostolic Faith Missions and Assemblies of God churches.

As the movement grew, its status changed from a despised fringe group to one with an increasingly elite status. Correspondingly, Macchia observes, with respect to North America, that Pentecostalism lost some of its ethos, such as its eschatological fervour. Additionally, he notes, the movement gradually

abandoned the urban poor for the suburban middle class. Storefront and tent meetings that tended to function as eschatological 'colonies' of enthusiastic believers were soon replaced by mega churches and ministries that focused attention on success for middle class Christians in the here-and-now. (Macchia 1996:34)

It was at this point that personal kingdom building began to supersede the kingdom-of-God perspectives on success. Such massive accumulations of wealth could not be willed off to non-family members. Accounting for this change in perspective nearly half a century ago, MacDonald (1981) wrote:

The Pentecostals and charismatics of the last half of the twentieth century have been considered in some respects as ecclesiastical orphans, step-children, or outright rebels. It is not surprising therefore that they are contributing so enormously to the contemporary formation of personal kingdoms to compensate for their perceived inferiority. (p. 29)

Whereas the Pentecostal movement came to Nigeria within the first half of the twentieth century, it began to experience its monumental growth within the last quarter of that century, through the rise of a multitude of African Instituted Churches and their embrace of the world, rather than the rejection of the world that was characteristic of classical Pentecostalism (Adeboye 2007:30). Understandably, that was the very era in which the rise of the prosperity gospel was rapidly crowding out the aforementioned classical Pentecostal ethos of the Pentecostal movement. Entrepreneurial motivation was thus lurking in the founding of many of such African Instituted Churches; hence, it became natural for them to also adopt modern marketing techniques in their operations 'and even adopt typical entrepreneurial techniques and aggression of the marketplace to promote themselves' (Adeboye 2007:30).

With the attendant huge financial success of such effort came the challenge of leadership succession. Faithful discipleship was no longer adequate for mentored followers to succeed their deceased leaders, but such heirs had to be either children or spouses of the leader. Setting forth mentoring as 
preparatory to succession (from a South African perspective), Ngomane points out that some leaders within the charismatic movement are beginning to express apprehension at the goit-alone approach of the their colleagues. He cites Oosthuizen as saying, 'in the Charismatic movement, leadership tends to be understood as something that is centred in a single person' (Ngomane 2013:50). Ngomane's research shows the pattern of failure to leadership mentoring among charismatic churches as arising from the fact that many of them are preoccupied with 'strategies for raising funds for their personal needs' (2013:51). Overall, his massive study of leadership mentorship among 348 leaders of 47 charismatic churches in Bushbuckridge, South Africa, shows that leaders in the charismatic movement are not perturbed by dynastic success; their only concern is that successors should be groomed and prepared before the demise of the founderpresident (Ngomane 2013:52).

The interesting thing about the study, as it relates to the present article, is that while the leaders overwhelmingly $(72 \%)$ claim (in the questionnaire responses) to have mentoring and leadership succession programmes going on in their churches, during focus group discussions the same church leaders claim that churches in Bushbuckridge had no mentoring and succession programmes (Ngomane \& Mahlangu 2014:3). Ngomane explains this cognitive dissonance thus:

It could be that in the focus groups, respondents responded truthfully but when asked in the questionnaire to indicate whether they themselves had leadership mentoring and succession programmes gave responses that seemed good to them in order for them to appear to be doing the right thing. If this was the case, then their credibility as church leaders is in question.

Because most of the time successors to charismatic church leaders are announced after their demise (Ngomane 2013:52), their lack of public preparation of successor implicitly connotes secret preparation that a family member succeeds them. It is in the light of all of these, then, that it becomes pertinent to examine the leadership structure and succession patterns of the New Testament and post-apostolic churches of the early Christian era.

\section{The structure and patterns of leadership development in the New Testament Church}

Although our primary focus is the structure of leadership in the New Testament churches, it is necessary to begin with an understanding of the leadership development, broadly speaking, from the origins of the church. I shall, therefore, take a cursory look at Jewish Christianity as a point of departure and then trace the various developments into the second century in the Common Era. In beginning with leadership of early Jewish Christianity, I am following the cue from Burtchael (2004:274), who in discussing early Christian leadership patterns goes all the way back to leadership in synagogal Judaism.

\section{Jewish Christianity}

Brown (1984:35) does not see the structuring of a society in the earthly ministry of Jesus Christ, nor does he see an organised church. Indeed, Brown says that Jesus selected the 12 apostles not to be administrators but eschatological judges of the renewed Israel (Mt. 19:28; Lk. 22:30). In that capacity, they were to be, first of all, witnesses to the redemption of humanity wrought by God in Christ Jesus (Lk. 24:46-48). Institutionalisation of the leadership structure, for Brown, arose once the eschatological movement begun by Jesus became organised into a society called the 'church' (Brown 1984:35). Loaded and questionable as Brown's assertion is, it has a kernel of truth - Jesus did not give the apostles an explicit blueprint for church leadership.

The book of Acts gives a picture of the evolution of leadership structure in the Jewish church in Jerusalem. When the church began its life, after the ascension of Jesus, it was governed by the apostles, who themselves were being guided by the Holy Spirit. At that time, there were no elders, deacons, bishops or anyone of the sort; governmental structure developed as the need arose (Boer 1976:27). It is significant to note, however, how the first recorded address of Peter highlights what constituted the nature of the role of the apostles within the group: it was a lot more encompassing. Miguens (1976:19) explains the nature of leadership in the nascent apostolic church (based on Peter's speech in Acts 1) thus, 'These Twelve have a particular topos, position (Ac. 1:25) which is, at the same time, one of diakonias, ministry and apostoles, apostleship, (1:25, i.e. they have a dignity which implies a ministry or service) (cf. v. 17); verse 20 refers to an episckope'. Burtchael (2004:283) equally takes cognisance of the fluidity of terms that Miguens acknowledges as he posits, 'At first they are called presbyteroi or episkopoi, or hêgoumenoi or poimenes: sometimes sharing a common designation with the elders and sometimes having one of their own'. Such fluidity of terminology further demonstrates the egalitarian nature of the 'assembly' (ekklesia) of believers. It was only with the skewing of power in the hands of singular individuals in latter times that the terms were purely functional descriptors began to assume set titular rank.

It is thus interesting to note that, from the beginning of the church, there was a position that was filled by the apostles, who also did the work of service (like deacons) and had the oversight (of bishops or elders). In other words, in the earliest days of the church, the apostles, in their oversight role combined both the kerygmatic, leadership and service functions of church workers. It is also important to note that, whereas Peter emerged as the leader or the spokesperson, the apostles acted corporately in collegial leadership of the egalitarian eschatological Messianic community. There was no priority of rank among them. Thus, Luke says that they acted in unison (Ac. 2:14, 37; 5:29), taught (Ac. 2:42), performed miracles (Ac. 2:43; 5:12), bore witness (Ac. 4:33), received gifts and distributed them to the community (Ac. 4:37; 5:2), were persecuted (Ac. 5:18ff, 29, 40), summoned a meeting and laid hands on the chosen deacons (Ac. 6:2, 6), remained in Jerusalem (Ac. 8:1), sent Peter and John to Samaria (Ac. 8:14) and received Paul (Ac. 9:27). 
After the emphasis on the equality and unanimity of all believers, Luke's introduction of the elders at the Jerusalem church (Ac. 11:30) is rather sudden. Curiously enough, he seems to assume that the reader knows when and how they were appointed; that is, he does not explain their origin as he does the origin of the deacons (Ac. 6:1-7). Whatever is said concerning the rise of elders, therefore, is more conjecture than documented fact. Thus, Boer suggests that, after Pentecost, the meeting of the believers might have been patterned after the synagogue model (Boer 1976:28). This is understandable, because with the phenomenal growth of the church in the events following Pentecost, the number of believers would have become too large to continue to meet as a single group. Thus, neighbourhood meetings would have sprung up following the synagogue pattern; this is more likely, because these believers were themselves Jews. Miguens (1976:35) notes that, with their Jewish background, elders 'appear as an element of the Sanhedrin in Jerusalem, as an element in the local synagogal Sanhedrins'. In the event of the rise of many house (or neighbourhood) churches, following the pattern of synagogues, it would have been natural to have elders overseeing these groups. These elders would probably have met with the apostles from time to time both to report and decide on issues that affected the church in Jerusalem at large. This would have been particularly likely, because at this point, the church did not see itself as separate from Judaism, and in Judaism the position of elders was linked to the 70 elders who worshipped with Moses at Mount Sinai (Reasoner 1993:719).

Lightfoot (1883:26), however, attributes the rise of elders in the Jerusalem church to the dispersal of the apostles after the martyrdom of James. Consequently, with Jerusalem becoming the less likely operational base of the apostles, 'it became necessary to provide for the permanent direction of the church there; and for this purpose the usual government of the synagogue would be adopted'. It is probable that it was not just one factor that gave rise to the institution of elders in the Jerusalem church but a combination of factors such as the two advanced above. Whatever the case, the elders came into being in the church. They initially shared in the governing of the church with the apostles (Ac. 15), but as time went on, it appears, they exclusively ruled the church (Ac. 21:18).

Thus far, I have shown that the church at Jerusalem was led at the beginning by the apostles as a group. Over time, the apostles gave over the diakonia (service) aspect of their work to the deacons (Ac. 6:1-7). At some point later, they shared the episkopes (oversight) aspect of their task with the instituted presbyters (elders; Ac. 15). It appears as if, at a still later point, they gave up (or was it taken over?) their episkopes position, left Jerusalem and devoted themselves to the original task given to them by Jesus as proclaimers of his eschatological kingdom to the nations (cf. Ac. 1:8; Mt. 28:19-20).

At the time the apostles were actively involved in the leadership of the Jerusalem church, leadership was a collegial affair, and there was a strong element of charismatism in the church, the rise of the presbytery notwithstanding (Ac. 4:31-37; 11:23-24, 27-30). It is also noteworthy that some of prophets were leaders in the Jerusalem Church (Ac. 15:22-23, 32).

\section{Gentile apostolic Pauline churches}

Holmberg (1978:196) envisions a three-level structure of church leadership at the time of Paul: global, regional and local. At the global level, the Jerusalem church or the apostolate there stood at the apex, and on a number of occasions, 'it appears that he [Paul] is permanently dependent in some respect on this center of the Church' (Holmberg 1978:196). He characterises the relationship between Paul and the Jerusalem church as an institutionalised charismatic authority relation, with the institutionalised charisma of Jerusalem dominating the relationship while at the same time acknowledging the authenticity and independence of Paul's charismatic authority (Holmberg 1978:197). Two reasons he advances for this dependency relationship are Paul's recent conversion coupled with the fact that the Antiochene church, in which he was both a leader and a missionary, 'considers itself bound in vital respect to its point of origin, the church in Jerusalem, as we can see from Galatians 2:1-14' (Holmberg 1978:197).

At the regional level, Holmberg (1978:197) observes that Paul exercised his authority over some of his missionary assistants and over the churches founded by him. He states that, in the churches that Paul founded, his authority was wide ranging and of great intensity, in that he acted as the representative of God and Christ. He says, however, that Paul, even in that capacity, tended to impose limits on the use of his apostolic authority, which in turn tended to weaken his authority, especially in churches that came under the influence of impressive intruders.

At the local level, Holmberg (1978:198) holds that, within a short time, functional differentiation in church leadership became institutionalised or developed into specific offices. Such differentiation, he says, arose largely by pneumatic and social differences within the local congregation but without much organisation on the part of Paul. The determining factor for how quickly such functional differentiation settled in a local congregation was the length of Paul's stay and how long he remained active in any of his churches. Thus, as long as he remained present or active in a church so long did its local offices remain undeveloped. He sees Paul's attitude to the development of local leadership as positive; he even consolidates it by authoritatively putting pneumatic and non-pneumatic functions on the same basis as being manifestations of the Spirit in the church (cf. Rm. 12:3-9; 1 Cor. 12:4-11, 28). Although institutionalisation, at least incipiently, was developing in the churches, Haag is of the opinion that the idea of some kind of 'superior authority' was alien to the early Christian communities. In Paul, Haag (1997:91) says, the prophets and teachers for instance, were not subordinate to, but exercised ministries alongside, the apostles (cf., 1 Cor. 12:28; Eph. 4:11; and esp. Eph. 2:20). This is not surprising, because, in the Antiochene church, from which Paul had gone forth as a missionary, prophets and teachers were very active as leaders (Ac. 13:1). Besides, as we have already seen, even in the Jerusalem church, the prophets were actively involved in the leadership of the church, together with the apostles, in the presbytery. 
Giving more attention to the structure of leadership at the local church level, Lightfoot (1883:35) says that the apostles themselves superintended over the churches that were under their care (those they founded) either in person or sometimes at a distance by a letter sent through apostolic delegates (such as Barnabas, Silas, Timothy and Titus). Even then, the apostles did not exercise such superintendence with the air of condescension but as fellows with either the entire membership (1 Cor. 5:3-4) or as fellow-elders (1 Pt. 5:1-6). However, as the church spread, the visits of the apostles became infrequent and far between, and, as such, the efficiency of their supervision of the churches became impaired. This led to the next stage of development in which the apostles, Paul in this case, would delegate trustworthy associates who would locate in a given place for a time and direct the affairs of the church there (Lightfoot 1883:35-36) (cf. 1 Tm. 1:3; Tt. 1:5; see also Phlp. 2:19-23; 1Th. 3:1-3; 1 Cor. $16: 10-12)$.

At this point, it is necessary to make a brief survey of Paul's use of the terms that relate to leadership structure in the undisputedly authentic Pauline letters. Robert M. Grant has made a good discussion of this and we do not intend to reproduce his work here but just an outline of his discussion for the purpose of illustration (Grant 1964:141-150). In the book of Romans, the local ministers owe their ministry to gifts of grace and they are listed in Romans 12:6-8. Paul speaks of Phoebe, who is a deacon in Cenchrea, and Andronicus and Junia, who were of note among the apostles $(16: 1,7)$. Philippians was addressed to 'the saints' in Philippi together with the bishops and the deacons (1:1). Later in the book, he wrote of other workers in the church as well (2:25-30; 4:1-3). In Colossians, there is no specific mention of offices as such. However, Epaphras was said to be a minister (diakonos) of Christ (1:7) and Archippus was urged to fulfil his ministry, diakonia (4:17). Ephesians contains a list of ministerial (functional) offices (4:11). All these give evidence that, in the Pauline churches, the offices of bishop (episkopos) and deacon (diakonos) existed alongside persons with the charismatic gifts to give leadership to the congregations. All these are mentioned in the plural.

\section{Gentile sub-apostolic Pauline churches}

The discussion, at this point, is focused on situations in the churches that are addressed by the letters whose Pauline authenticity is questioned by critical scholarship. Use of the term 'sub-apostolic' is not indicative of my subscription to the view of critical scholarship that denies their Pauline authenticity. Whatever their provenance, they addressed situations that were anticipatory of the absence of Paul, especially as the end of his life was imminent. Be that as it may, they (especially the Pastorals) are considered sub-apostolic in the sense that they were a development from the era of actual personal active ministerial presence of the Apostle Paul in those churches to one in which he was personally absent.

Grant (1964:155) places the Pastorals somewhere after the AD 70. Conservative evangelical scholarship would, however, prefer a date earlier than AD 70 (Ellis 1993:658-666). Whatever the case is, they are a later development than the other Pauline letters. Indeed, Grant shows that these letters evince a symbiotic relationship between the original itinerant charismatic leadership and the emerging sedate pedestrian leadership. Charismatism is still present through prophecies and laying-on of hands (1 Tm 1:18; 4:14; 5:22; 2 Tm 1:6; Tt 1:5). At the same time, there is an emerging hierarchy whereby the persons appointed and ordained are divided into two categories. Firstly, the less significant deacons group, which consists of women and men (1 Tm 3:8-13); and secondly, the elite group of elders or presbyters, who not only preach but also can lay hands on others (1 Tm. 3:1-7; 5:17-22) (Grant 1964:154). In this group of letters, the terms presbyteros and episkopos are used interchangeably (Tt. 1:5-7; 1 Tm. 3:1; 5:17). This agrees with Luke's view, where Paul is pictured as taking the terms to be synonyms. He is said to have sent to fetch the presbyterous of Ephesus (Ac.20:17), but in the address to them he told them to take care of the flock over which the Holy Spirit has made the episkopous (Ac. 20:28).

The picture of church leadership structure in the subapostolic church shares a basic affinity with that which we saw in the apostolic Pauline churches. There is a basic twotier structure of (1) deacons, among whom women were included (Rm. 16:1;1Tm. 3:813) and (2) presbyters or bishops, who governed, taught and cared for the congregation (Phlp. 1:1; 1 Cor. 16:15-16; 1 Tm. 5:17).

In spite of this similarity, there is an emerging institutionalisation. Firstly, there is a shift of emphasis from pneumatic leaders who use the charismata of the Spirit for the edification of the church (Rm. 12:3-8; 1 Cor. 1:7; 1 Cor. 12-14; 2 Cor. 8:7) to pedestrian institutional moral qualities (1 Tm. 3:1-13; it. 1:5-9). Secondly, there is a development in the amount of power wielded by the apostolic delegates. In the earlier letters of Paul, he had to make passionate appeals for their acceptance (1 Cor. 16:10-11; 2 Cor. 12:17-19) or pay glowing tribute to them to secure their acceptance (Phlp. 2:19-30). Indeed, even Paul himself had to argue or explain himself in order to prepare the way for his own visit, even in churches that he had founded (2 Cor. 1:12-24; 2:1; 12:19-21; 13:1-3). But the situation is different in the sub-apostolic churches. The apostolic delegates are fully in-charge, and they are the ones who determine the course of things, not the congregation. In the Corinthian correspondence, it is the church that was urged not to make Timothy afraid nor despise him (1 Cor. 16:10-11), and it is the church that was to execute discipline (1 Cor. 5:3-5). But in the sub-apostolic church, it is the apostolic delegate who determines the course of things. He is the one who should not allow himself to be intimidated ( $1 \mathrm{Tm} .4: 12)$; he is the one to appoint the presbyters or bishops and deacons (Tt. 1:5); he is the one who determines what is taught (1 Tm. 1:3; 6:3-5; Tt. 1:10-11).

All this taken together, we see the rise of a system developed within the Pauline tradition for effective succession on the basis of faith and character, rather than filial lineage. Commenting on Paul's ministry approach, MacDonald 
writes, 'My thesis here is that the Apostle Paul's ministry was intentionally precedent setting and has never been superseded by a better methodology more compatible with the kingdom of God' (MacDonald 1981:37). MacDonald's assessment cannot be gainsaid, even in our times. It is fitting for a church which claims to be apostolic, therefore, to remain loyal to its roots even in matters of succession.

\section{Leadership structure and succession patterns in the early patristic era}

The New Testament does not offer a treatise on leadership succession, but the above discussion has sketched out a clear pattern that emerged in the apostolic and post-apostolic churches. Therefore, in this section, we will explore the development of church leadership in the early patristic era and its implication on succession.

According to Schindler (1981:4), church government in an autonomous local body in the New Testament was by a plurality of elders who were assisted in their responsibility by deacons; such a group was called a presbytery; at that time, the terms elder and bishop were used interchangeably. However, by early second century, Ignatius had modelled a structure of church government in which the bishop was elevated to the higher pedestal of a monarch. The Ignatian model spread rapidly in the second century from the east (in Syria) to the west (as far as Rome). By the third century, Cyprian (following the steps of Irenaeus) had further developed the authority of the bishop. He enhanced this development with the concept of unbroken apostolic succession of bishops from Peter to the legitimate bishop in every catholic church (Schindler 1981:4).

Lightfoot (1883:39) has noted that, whereas as late as 70 A.D. there were no distinct signs of episcopal government in Gentile Christendom, by the early second century, episcopacy seems to have been firmly established. On a similar note, Burtchael (2004:274) characterises the disparity in church leadership in the first two centuries of the Common Era thus:

Put schematically, the church of the New Testament and the church of 'the Apostolic Fathers' appear to embody, respectively, charismatic and official traditions of leadership that are characterised by associated contrasts: lay vs clerical, congregational vs hierarchical, voluntary vs professional. (Burtchael 2004:274)

While noting that this change came about in the last three decades of the first century, Lightfoot (1883:39) also observes, 'the circumstances under which it was effected are shrouded in darkness; and various attempts have been made to read the obscure enigma'.

Whereas Ignatius's appropriation of Paul in the former's letters is inadequate (if not inappropriate), as far as the structure of church leadership is concerned, there is an important point the apostolic and post-apostolic church fathers (Ignatius, Irenaeus and Cyprian) underscored with respect to leadership succession: their focus was on theological and spiritual pedigree and not familial connections.
Observations on leadership structure and succession patterns in the New Testament church

From the foregoing analysis of the leadership structure and succession pattern of the New Testament church, the following observations are drawn:

1. Jesus had established a collegial leadership, in the apostles, for the eschatological community of the Spirit he was setting up, with Simon Peter as the spokesperson of this group.

2. Jesus did not hand over the leadership of his newly established eschatological community to his cousins, James and John, who were his closest relatives in his band of disciples.

3. The collegial pattern of leadership and the emergence of leaders on the basis of gifting continued in the era of the church, captured in the book of the Acts of the Apostles, even with the rise of the diaconate and the presbytery.

4. The apostolic churches had the direct superintendence of the apostles as Christ's representatives. In the absence of the apostles, apostolic delegates were appointed to represent them on the basis of the soundness of their faith, doctrine and lives, through the mentorship of the apostles, not on kin relationship.

5. In the sub-apostolic era, with the (imminent) martyrdom of the apostles, the elders and deacons were appointed to lead the churches on the basis of their faith, character, adherence to sound doctrines and the traditions handed down by the apostles (1 Tm. 3:1-13; Tt. 1:5-9) not familial affiliation.

6. Even in the post-apostolic church, the writings of the church fathers indicate that adherence to apostolic faith, life and traditions were determinative for the appointment of church leaders (bishops) to succeed the apostles (Irenaeus, Against Heresies 3.3.1-4).

7. The non-apostolic writers of the Gospels (Mark and Luke) did not attain that status because of familial affinities but ministerial tutelage (Irenaeus, Against Heresies 3.1.1).

\section{Succession patterns of neo-Pentecostalism}

Having established the succession patterns, both in the New Testament and early patristic church eras, we now return to examine the succession patterns in contemporary neo-Pentecostalism. One of the leading apostles of this neo-Pentecostal movement, Kenneth E. Hagin, left the Assemblies of God in the mid-1960s to establish his own ministry, which grew into a massive empire. Before his death in 2003, his son, Kenneth Hagin, Jr., was already established as heir apparent (Robins 2010:131). Kenneth Copeland, a protégée of the senior Hagin, has followed and surpassed the example of Hagin: His wife Gloria and their three children work in his ministry. His son John is its chief operating officer; daughter Terri Pearsons preaches with her husband, who is a pastor at the Copelands' Eagle Mountain International Church; and daughter Kellie Swisher is also a minister within the 
ministry. Even the much-revered Billy Graham (who is neither Pentecostal nor Charismatic) bequeathed his Billy Graham Evangelistic Association to his son Franklin, who was already deeply occupied (heart and soul) with the relief and compassion ministry of Samaritan's Purse, which he had inherited from Bob Pierce (a non-relative) after the latter's death in 1978. Robert Schuller seems to have pinpointed his son Robert A. Schuller as heir apparent. However, in the absence of a clear path to succession anchored in discipleship and mentored, as signs of dementia plagued Schuller senior, sibling rivalry and family intrigued drove Schuller junior out of the ministry and run the ministry aground. It became bankrupt and its Crystal Cathedral was sold to Orange County Catholic Diocese (Banks 2012).

Because the American Pentecostal or charismatic preachers had such huge influence on emergent neo-Pentecostalism in Nigeria, it was natural that their succession pattern would also become the norm in Nigeria. A few examples will suffice. After the sudden demise of the late Archbishop Benson Idahosa in March 1998, the Nigerian Apostle of Faith, his wife Margaret took over the reins of power at the Church of God Mission International and is still its presiding bishop and president. Currently, his son, Bishop Faith Emmanuel Benson Idahosa, is the president of the Benson Idahosa University, the president of Big Ben's Children Hospital and the vice president of All Nations for Christ Bible Institute International, among many other positions within the ministries of Church of God Mission International. When the Reverend Godwin Ikyernum (of New Anointing Ministries, Makurdi) died in an auto crash in March 1997, his wife took over the leadership of the ministry, to the chagrin of some of the late minister's close ministry associates, who eventually left the ministry (based on an interview of an associate of the late Rev. Ikyernum in Makurdi, 2014). At present, the ministry is led by his son, Pastor Joshua Ikyernum. These stories could be replicated again and again.

In the midst of all this, one finds the succession story of the Redeemed Christian Church of God from its founder to the present General Overseer very fascinating. The founder of the church, Josiah Olufemi Akindayomi, a child of classical Pentecostalism, had learned the importance of team leadership inherent in classical Pentecostalism. Thus, right from the beginning, he took his team members into confidence, and any time he went on his frequent evangelistic campaigns, he left his headquarters church in the care of resident pastors. He even chose a person more educated than himself (Pastor Olonade) to set up and run the bureaucracy of the church (Adeboye 2007:37). It is, therefore, not surprising that, at his death, Pa Akindayomi did not bequeath his church to a relative; rather, he bequeathed it to a person whom he foresaw would bring to fruition what the Lord had revealed to him concerning what has come to be called the Redeemed Christian Church of God Covenant. It remains to be seen whether Pastor E.A. Adeboye, an arrowhead in neo-
Pentecostalism, will follow the example of Pa Akindayomi or be swept along by the established succession current of neoPentecostalism.

\section{Recommendations for contemporary leadership succession}

Juxtaposing the leadership succession of contemporary Pentecostals vis-à-vis apostolic and patristic praxis leaves much to be desired. The core determining factor is perspective on ministry: Kingdom-of-God versus personal kingdom. Modern Pentecostals have increasingly been decoyed by the lure of the world's material prosperity. In the massive primitive accumulation of wealth concomitant with the wealth and wellness gospel, leadership becomes less accountable and transparent with its membership, and the need to surround itself with trusted confidents rises correspondingly, hence the heavy reliance on family members. Andy Hargreaves' thoughts on leadership succession in education are pertinent here. He writes, 'But without strong systems, increased transparency, and greater emotional honesty and support, many of us handle succession moments badly - in relation to others and also in terms of ourselves' (Hargreaves 2010:xiii). Unfortunately, this is the story of the Pentecostal movement at the moment.

The collegial leadership style of the New Testament Apostolic church, espoused in classical Pentecostalism, has been replaced in the neo-Pentecostal movements by sole proprietary managerial leadership patterns. Lack of financial transparency results in cronyism or nepotism and familial succession practices. It is the uncertainty that these family-centred practices create for faithful disciples of Pentecostal leaders that, in large part, account for the breakaways and formation of new ministries to ensure personal financial survival. To counter this trend and encourage the return to true biblical apostolic ministry, the following proposals or recommendations have been drawn from the study of the New Testament church structure and succession patterns:

1. Team leadership is the biblical pattern of leadership (as has been demonstrated in our survey of the New Testament church leadership pattern), usually with an individual as the point-person of the team, and should be espoused by all Christian ministries.

2. Following in the example of Jesus, familial affiliation should not be the criterion for advancing in the leadership hierarchy, leading to succession in a Christian ministry setting.

3. Rise in rank in leadership hierarchy in ministry should be based on people's gifting and ministry calling.

4. Closely related to the above, people should be called to serve in positions of responsibility on account of their testimonies of unquestioned faith, with abiding love for God and the brotherhood in Christ, impeccable Christian character, soundness in doctrine and faithfulness to established traditions (1 Tm. 3:1-13; Tt. 1:5-9). 
5. There should be deliberate and conscientious efforts towards raising and mentoring succeeding generations of leaders as the case was in the apostolic church, rather than waiting to pass on the ministry legacy to family members, like a hereditary monarchy.

\section{Conclusion}

This article began with the proposition that perspective on ministry is determinative of the approach to leadership style and the pattern of succession that will be set in place. Two dominant ministry perspectives were highlighted, namely the kingdom-of-God perspective and the personal kingdom perspective. It was shown that those with the former perspective have a high propensity to adopt a collegial leadership style and more often than not tend to be succeeded by subordinates, who have the appropriate calling and have most imbibed the ethos of the faith and the ministry. On the other hand, where personal kingdom orientation is the dominant perspective, there is a higher tendency to be secretive and less transparent in leadership style, and succession usually goes to trusted inner-circle family members. It then reviewed the rise of and the essential attributes of classical Pentecostalism.

In the course of the article, the New Testament (apostolic) leadership structure and succession patterns were surveyed. This was carried out by looking at the leadership structure of Jewish Christianity, apostolic Gentile Christianity and the sub-apostolic Gentile Christianity. References were also made to the leadership structure and succession patterns of the post-apostolic (patristic) church. Salient features of all these were abstracted from the detailed study. This was followed by a quick look at the prevailing succession patterns of key neo-Pentecostal and Charismatic groups both in America and Nigeria and shown to be contrary to the New Testament church pattern. From the study, salient points were drawn to form recommendations for a New Testament leadership structure and succession pattern for contemporary Christian ministry.

Finally, the Pentecostal church of the twenty first century must return to its root (recursus ad fontes). This will be the surest way of ensuring that it remains faithful to the gospel of our Lord and Saviour Jesus Christ and not become a creator of another gospel, which is happening in a number of circles.

\section{Acknowledgements Competing interests}

The author declares that he has no financial or personal relationships which may have inappropriately influenced him in writing this article.

\section{References}

Adeboye, O., 2007, '“Arrowhead" of Nigerian Pentecostalism: The Redeemed Christian Church of God, 1952-2005', Pneuma 29, 24-58.

Banks, A.M., 2012, 'Crystal Cathedral: Robert A. Schuller Says Sibling Rivalry Fueled Downfall', viewed 10 June 2016 from http://www.huffingtonpost.com/2012/ 03/22/crystal-cathedral-robert-schuller-downfall_n_1368321.html

Boer, H.R., 1976, A short history of the early church, Eerdmans, Grand Rapids, MI.

Brown, R.E., 1984, The churches the apostles left behind, Paulist Press, New York.

Burkett, R.K. \& Newman, R. (eds.), 1978. Black apostles: Afro-American clergy confront the twentieth century. G. K. Hall, Boston, MA.

Burtchael, J.T., 2004. From synagogue to church: Public services and offices in the earliest Christian communities, The Cambridge University Press, Cambridge, MA.

Cauchi, T., 2004, 'William Seymour and the history of the Azusa Street outpouring', viewed 21 May 2014, from http://www.revival-library.org/pensketches/am pentecostals/seymourazusa.html

Ellis, E.E., 1993, 'Pastoral letters', in G.F. Hawthorne, R.P. Martin \& D.G. Reid (eds.), Dictionary of Paul and his letters, pp. 658-666, IVP, Downers Grove, IL.

Grant, R.M., 1964, The apostolic fathers: A new translation and commentary. Volume 1: An introduction, Thomas Nelson \& Sons, New York.

Haag, H., 1997, Clergy \& laity: Did Jesus want a two-Tier church?, trans. B. Robert Nowell, T.W. Oates \& V.T. Kent, Originally published by Verlag Herder, Freiburg im Breisgau.

Hargreaves, A., 2010, 'Foreword', in D. Fink (ed.), The succession challenge: Building and sustaining leadership capacity through succession management, pp. xi-xvi. Sage, London.

Holmberg, B., 1978, 'Paul and power: The structure of authority in the primitive Church as reflected in the Pauline epistles', Coniectanea Biblica New Testament Series II, Doctoral thesis, Lund University, Lund.

Lightfoot, J.B., 1883, The Christian Ministry. Thomas Whittaker, New York.

Macchia, F.D., 1996, 'God present in a confused situation: The mixed influence of the charismatic movement on classical pentecostalism in the United States', Pneuma 18(1), 33-54.

MacDonald, W.G., 1981, 'The cross versus personal kingdoms', Pneuma 3(2), 26-37.

Miguens, M., 1976, Church Ministries in New Testament times, Christian Culture Press, Arlington, VA.

Morris, L., 1982, 'John the Apostle', in G.W. Bromily (ed.), International standard Bible encyclopedia, pp. 1107-1108, Eerdmans, Grand Rapids, MI.

Ngomane, R.M., 2013, 'Leadership mentoring and succession in charismatic churches in Bushbuckbridge', Unpublished doctoral dissertation, University of Pretoria, Pretoria.

Ngomane, R.M. \& Mahlangu, E., 2014, 'Leadership mentoring and succession in the charismatic churches in Bushbuckridge', HTS Teologiese Studies/Theological Studies 70(1), Art. \#2065, 10 pages, http://dx.doi.org/10.4102/hts.v70i1.2065

Reasoner, M., 1993, 'Political systems', in G.F. Hawthorne, R.P. Martin \& D.G. Reid (eds.), Dictionary of Paul and his letters, pp. 718-723, IVP, Downers Grove, IL.

Robins, R.G., 2010, Pentecostalism in America, Greenwood Publishing Group, Santa Barbara, CA.

Schindler, J., 1981, 'The rise of one-bishop-rule in the early church: A study in the writings of Ignatius and Cyprian', Baptist Reformation Review 10(2), 3-9.

Tinney, J.S., 1976, 'William J. Seymour: Father of modern-day pentecostalism' The Journal of the Interdenominational Theological Center 4(1), 34-44.

Turner, C., Jr., 2007, 'An East Coast celebration of Azusa: Theological implications', Journal of Pentecostal Theology 16(1), 32-45. 